\title{
PAŽINTINIŲ FUNKCIJU巳 IR EDUKACINIŲ PASIEKIMŲ SĄSAJOS BESIMOKANČIO JAUNIMO POPULIACIJOJE
}

\author{
Dalia Antinienė, Rosita Lekavičienė \\ Kauno technologijos universitetas, Kaunas, Lietuva
}

\begin{abstract}
Dalia Antinienẻ. Socialinių mokslų (sociologijos) daktarè. Kauno technologijos universiteto Psichologijos katedros docentė. Mokslinių tyrimu
\end{abstract} kryptis — tautinis tapatumas, socialiniai tinklai, neigaliujų socializacijos problemos.

\section{SANTRAUKA}

Pažintiniai gebèjimai - tai gebejjimai pasinaudoti pažintinèmis funkcijomis: dèmesiu, atmintimi, loginiu, erdviniu mastymu ir pan. Paprastai jie asocijuojasi su daugeliu išorès kintamuju, tačiau ypatingas ryšys juos sieja su edukaciniais pasiekimais. Užsienio mokslininkai konstatuoja aukštas šiu fenomenu koreliacijas. Lietuvoje vykdytu panašiu tyrimu atrasti nepavyko, nors žinant konkrečios amžiaus grupès žmoniu specifinius pažintinius gebëjimus galima bütu pakankamai tiksliai prognozuoti mokymosi pasiekimus.

Tyrimo tikslas - atskleisti, kaip besimokančiuju pažintinès funkcijos siejasi su edukaciniais veiksniais: edukacijos lygiu, mokymosi pasiekimais, subjektyviu pasiekimu vertinimu. Tyrimo uždaviniai: pateikti Pažintiniu gebèjimu vertinimo metodikos patikimumo rodiklius; atskleisti skirtingu edukacijos lygiu besimokančiuju pažintiniu gebejimu ypatybes ir jas palyginti tarpusavyje; nustatyti, kaip susijęs skirtingas edukacijos lygis bei subjektyvūs ir objektyvūs žiniu vertinimai su besimokančiuju pažintiniais gebèjimais.

Pažintiniu gebëjimu tyrimo metodikq sudaro šios struktūrinès dalys: dèmesingumo, loginio mastymo, skaitmeninio mastymo, dvimačio ir trimačio erdvinio mastymo ir aritmetiniu skaičiavimu užduotys. Metodikos patikimumas yra pakankamas. Vidine metodikos struktūra yra gera. Greta Pažintiniu gebëjimu vertinimo metodikos tiriamiesiems pateiktas Raveno progresuojančiu matricu testas ir Verbalinio išprusimo testas (autorius G. Merkys). Buvo tiriami 226 respondentai. Tyrimas atliktas ¿vairaus lygmens mokymosi institucijose: universitetuose, kolegijose, aukštesniosiose mokyklose, bendrojo lavinimo mokyklose ir gimnazijose.

Nustatyta, kad metodika gerai diferencijuoja skirtingo edukacijos lygio tiriamuosius. Gauti pakankamai ryškūs pažintiniu gebejjimu skirtumai aukštos ir žemos edukacijos tiriamuju grupèse: aukštesni pažintiniu gebejjimu skaliu rodikliai gauti aukšto edukacijos lygio tiriamuju grupése. Subjektyvus tiriamuju savo pačiu mokykliniu žiniu juvertinimas parodè visu pažintiniu gebejimu skaliu ryš̨ su tiksliuju mokslužiniu subjektyviu ìvertinimu. Objektyvūs besimokančiuju žiniu vertinimai (t. y. egzaminu vidurkiai) yra statistiškai patikimai susiję su visais pažintiniu gebejjimu metodikos skaliu vertinimo vidurkiais.

Raktažodžiai: pažintinès funkcijos; edukaciniai pasiekimai, žemas ir aukštas edukacijos lygis.

\section{IVADAS}

$\check{Z}$ mogaus pažintiniai gebejjimai glaudžiai susiję su išsimokslinimu, išlavinta atmintimi ir kryptingu pastabumu. Kitaip tariant, tai intelekto veiksmai, reikalingi problemų analizei, sprendimų prièmimui, kūrybingumui ir tiesiog normaliam asmens funkcionavimui. Juos taip pat galima būtų apibrež̌ti kaip gebejjimą pasinaudoti tam tikromis pažintinèmis funkcijomis: dèmesiu, loginiu, erdviniu mąstymu, atmintimi ir kt. (As- hcraft, 1989). Pažintiniai gebejjimai laikomi dideliais, kai asmuo moka ir gali pasinaudoti minetais intelektinès sistemos komponentais, sèkmingai spręsti problemas ir gerai mokytis. Visgi pažintiniai gebèjimai yra ne vien mokèjimas sẻkmingai iveikti mentalines užduotis, bet kartu ir gebejjimas jas atlikti greitai. Taigi svarbus ir mentalinių užduočių atlikimo tempas (Eysenck, 1987; Kyllonen, 1993; Neubauer, 1997; Fink, Neubauer, 2005). 
Pastaruoju metu mokslininkai prieina prie išvados, kad pažintiniai gebejjimai yra susiję su plačia juos paveikiančių gyvenimo ịvykių ir aplinkybiu skale: mokymosi ir profesiniais pasiekimais, edukacijos lygiu, profesine karjera, socialiniu-ekonominiu statusu, psichine sveikata ir pan. (Herrnstein, Murray, 1994; Gottfredson, 2004).

Daugeliui sąvoka pažintiniai gebejjimai, ko gero, labiausiai asocijuojasi su gebejimu išmokti (Cianciolo, Sternberg, 2004). Dèl to šis ryšys pedagoginès psichologijos srityje yra ypač plačiai tyrinėjamas (Kuncel et al., 2004; Spinath et al., 2006). Tyrèjai akcentuoja pažintinių gebejjimų ir edukacinių pasiekimų sąsajas (Ackerman, 1996; Ackerman, Rolfhus, 1999 ir kt.). Tačiau vieni autoriai teigia, kad dideli pažintiniai gebejjimai lemia didelius edukacinius pasiekimus, tuo tarpu kiti pastebi, kad dideliu pažintinių gebejimų asmenys gali turèti menkus mokslo pasiekimus, arba atvirkščiai — žmonès, kurių pažintiniai gebèjimai prasti, gali pasiekti mokslo aukštumų. Pavyzdžiui, 1973 m. JAV mokslininkai, atlikę plataus masto tyrimą, nustate, kad net 55\% Niujorke gyvenančiu dideliu gabumu mokinių mokosi prastai, o 19\% blogai besimokančių paauglių yra gabūs (Lupart, 1992). Pasirodè, kad gabūs mokiniai, kurių pasiekimai menki yra neatsparūs stresui, nerimastingi, pesimistai prastai save vertina, bijo nesèkmès arba turi kitu psichologiniu problemu.

Visgi reikia sutikti su daugumos mokslininku nuomone, kad ryšys tarp šių fenomenu yra ir, ko gero, abipusis (Watkins et al., 2007). Empiriniais tyrimais nustatyta, kad bendrojo intelekto ir edukaciniu pasiekimų koreliacija paprastai svyruoja apie 0,50 (Gustafson, Undheim, 1996). Tačiau yra ir tokių tyrimu, kurių koreliacija siekia net 0,80 (Deary et al., 2007). Didele koreliacija tarp mokymosi pasiekimų ir mentalinių gebejimų dažnai laikoma vienu iš reikšmingiausių tiriamo dalyko patikimumo argumentų.

Apibendrinant galima teigti, kad užsienio mokslininku patirtis yra daugialypè. Taigi pažintinių gebėjimų ir edukacinių pasiekimų ryšys nèra vienareikšmiškas ir aiškus. Todèl pažintiniu gebejjimų ir edukaciniu pasiekimu problema išlieka aktuali ir reikalaujanti naujų empirinių tyrimų.

Pastaruoju metu Lietuvos aukštosioms mokykloms svarbu tinkamai atrinkti studentus. Paprastai atranka į aukštają mokyklą vyksta remiantis abiturientų mokyklinių pasiekimų rezultatais. Tačiau kai kurių universitetų ir akademijų studentams būtini tam tikri specifiniai gebėjimai (pvz., Kūno kultūros, Karo, Dailès akademijos ir kt.), kadangi pati jiems numatoma veikla reikalauja visapusiškų intelektinių gebejjimų: abstraktaus mąstymo, matematinių bei erdvinių gebėjimų, greitos reakcijos, geros dèmesio koncentracijos ir pan. Todèl tokiu atveju tikslinga taikyti papildomą specialų atrankos būdą, leidžianti apčiuopti šiuos ypatumus ir suranguoti pretendentus pagal kognityviujų gebejjimų išreikštumo lygi. Šiuo tikslu paprastai naudojamos tokios metodikos kaip Raveno progresuojančių matricų testas, Amthauerio testas ir kt. Tačiau dèl santykiškai lengvo kiekvieno suinteresuoto asmens šių testų pasiekiamumo, jie ne visada gali būti naudojami išskirtinai svarbioms atrankoms atlikti.

Užsienio šalyse - Vakarų Europoje, JAV pažintiniu gebejimu testai plačiai taikomi tiek besimokančiuju profiliavimo, tiek profesinès atrankos metu. Nepaisant to, pažintinių funkcijų psichometrinių matavimu poreikis įvairiose gyvenimo srityse (pvz., profesinès atrankos, talentu paieškos ir pan.) kol kas dar dideja (Boyatzis, 2008 a, 2008 b; Leonard, 2008). Dèl to kuriami vis naujesni intelekto ir specifiniu pažintiniu gebejjimų testai (Robinson, 1999; Lohman, Hagen, 2001). Lietuvoje intelekto testai ar kitos pažintiniu funkcijų matavimo metodikos ilgą laiką buvo dažniausiai naudojamos protinei negaliai diagnozuoti. Taigi praktinè tokio tipo metodikų kūrimo būtinybe šalyje iškilo palyginti neseniai.

Straipsnyje pristatomo tyrimo metu buvo naudotas originalus pažintinių gebėjimų vertinimo būdas, ateityje numatytas taikyti stojančiuju i viena šalies universitetą jaunuolių, kurių būsima profesija kelia tam tikrus specifinius pažintiniu gebejjimu, atrankos reikalavimus. Atlikto užsakomojo mokslinio-taikomojo tyrimo tikslas buvo parengti ir testu teorijos bei psichometrinès statistikos priemonèmis patikrinti metodika, matuojančią tam tikrus pažintinius gebejjimus. Vèliau naudojant šią originalią tyrimo metodiką atliktas plataus masto tyrimas ivvairaus lygmens mokymosi institucijose: atlikta tyrimo būdo standartizacija ir ieškota pažintinių funkciju sąsajų su edukacinėmis tiriamujų ypatybėmis.

Šio tyrimo tikslas - atskleisti, kaip besimokančiujų pažintinès funkcijos (priklausomas kintamasis) - dèmesingumas, loginis, skaitmeninis, erdvinis mąstymas, aritmetinių skaičiavimų kokybé - siejasi su kitais veiksniais (nepriklausomais kintamaisiais) - edukacijos lygiu, mokymosi pasiekimais, subjektyviu pasiekimų vertinimu.

\section{Uždaviniai:}

- Pristatyti originalią Pažintinių gebejjimų vertinimo metodiką ir pateikti metodikos patikimumo rodiklius. 
- Atskleisti skirtingų edukacijos lygiu besimokančiuju pažintiniu gebejjimu ypatybes ir jas palyginti tarpusavyje.

- Nustatyti, kaip skirtingas edukacijos lygis ir subjektyvūs žinių vertinimai susiję su besimokančiuju pažintiniais gebejjimais.

- Nustatyti, kaip skirtingas edukacijos lygis ir objektyvūs žinių vertinimai susiję su besimokančiujų pažintiniais gebejjimais.

\section{TYRIMO METODIKA}

Apklausa vyko 2007 metais. Iš viso apklausti 226 respondentai. Tiriamieji - universitetu $(\mathrm{n}=88)$, kolegijų $(\mathrm{n}=59)$ ir aukštesniujų mokyklų $(\mathrm{n}=20)$ studentai, bendrojo lavinimo mokyklų $(\mathrm{n}=39)$ ir gimnazijų $(\mathrm{n}=20)$ mokiniai. Respondentai apklausti kokybiškai pasirenkant tikslines grupes. Renkantis lizdus atsižvelgta $i$ ivairius veiksnius, pavyzdžiui, norèta apklausti kuo ivvairesniu mokslo krypčiu, skirtingu studiju lygių studentus, skirtingo prestižo universitetuose, kolegijose ir aukštesniosiose mokyklose besimokančius jaunuolius. Tyrimui atrinktu asmenų vidutinis amžius - 19,8 m., standartinis nuokrypis $\mathrm{SD}=3,71 \mathrm{~m}$. Ištirta 119 moterų ir 107 vyrai.

Tyrimo metodas. Kaip minèta, tyrimas atliktas iqvairaus lygmens mokymosi institucijose. Tyrimas vyko grupemis po 10 tiriamujų. Kiekvienas tiriamasis turejo skirti tyrimui apie dvi su puse valandos. Tiriamiesiems buvo pateikta: a) originali Pažintinių gebejjimų tyrimo metodika (testas); b) anketa, skirta respondentu biografiniams ir demografiniams rodikliams nustatyti; c) Raveno progresuojančių matricų testas; d) Verbalinio išprusimo testas (autorius G. Merkys). Vieno tiriamojo duomenu eilutę matricoje sudaro 475 kintamieji, tad iš viso matricoje yra 107350 kintamujų.

Pažintinių gebejjimų tyrimo testas parengtas kelių mokslininkų (R. Lekavičienès, D. Antinienès, konsultanto G. Merkio) - tai atskiros užduočiu grupès, orientuotos ị kai kuriu pažintinių funkcijų tyrimą. Metodiką sudaro penkios struktūrinès dalys: dèmesingumo, loginio mąstymo, skaitmeninio mąstymo, dvimačio erdvinio mąstymo ir aritmetiniu skaičiavimu užduotys. Taip pat parengta atsakymu lapo forma, bendra tyrimo metodikos instrukcija ir instrukcijos atskiroms užduotims vykdyti.

Démesingumo užduotys. Parengta šešiasdešimt užduočiu, kurioms spręsti skiriamos penkios minutès. Pasibaigus skirtam laikui, sprendimas stabdomas. Tiriamasis turi įsidemėti tam tikrą ženklų kombinaciją ir pasirinkti iš keturių pateiktų galimu vieną varianta, atitinkanti anksčiau isidèmètą kombinaciją, ir ji pažymèti atsakymų lape.

Loginio mastymo užduotys. Parengta trisdešimt spalvotų grafinių užduočių, kurioms spręsti skiriama dešimt minučių. Kiekvienoje užduotyje yra pateikiamos trys tam tikra logine seka pasuktos figūros. Tiriamojo užduotis - atsakymu lape teisingai pažymèti ketvirtą logiškai tinkamą figūrą pasirenkant iš keturių pateiktų variantų $\mathrm{A}$, B, C, D.

Skaitmeninio mastymo užduotys. Parengta trisdešimt užduočių, kurioms spręsti skiriama septyniolika minučiuc. Kiekvienoje užduotyje yra pateikiamos trys skaičiu diagramos, susijusios tam tikra aritmetinių skaičiavimų dėsningumo logine tvarka. Tiriamojo užduotis - išsirinkti ir atsakymų lape teisingai pažymèti ketvirtą diagramą, kuri būtu sudaryta ta pačia skaičiavimo tvarka.

Dvimačio erdvinio mastymo užduotys. Pateikiama dvidešimt spalvotu užduočiu, kurioms spręsti skiriamos penkios minutès. Tiriamasis iš keturių pateiktų variantų turi išsirinkti tą kurị prijungus prie plokštuminès detalès su iškirpta dalimi būtų gauta visa figūra. Kitaip tariant, reikia atrasti figūros dali, tinkančią pagal formą ir rašta.

Aritmetiniu skaičiavimu užduotys. Parengta šešiasdešimt užduočių, kurioms spręsti skiriamos aštuonios minutès. Tiriamasis turi atmintinai atlikti gana paprastus aritmetinius veiksmus, pasirinkti iš keturių variantų vieną atsakymą ir ji pažymèti atsakymų lape.

Atlikę šias penkių rūšių užduotis, tiriamieji turi dar kartą atlikti jau minètą (pirmą) dẻmesingumo užduoti, kuriai ši kartą skiriama mažiau laiko - keturios minutès. Taigi iš viso metodiką sudaro šešios užduočiu grupès.

Visi norintys plačiau susipažinti su originalia Pažintinių procesų tyrimo metodika, jos rengimo ypatumais, paskatos medžiaga ir pan. gali ją rasti R. Lekavičienès ir D. Antinienès straipsnyje „Kognityviniu gebejimu vertinimo metodikos konstravimo ir standartizavimo problemos", išspausdintame žurnale „Profesinis rengimas: tyrimai ir realijos“" (2007 / 14).

\section{REZULTATAI}

Kadangi naudojama originali tyrimo metodika, tai ją sukūrus privalu patikrinti testo patikimumą. Naudotas regresinès analizès modelis: testo patikimumas tikrintas lyginant ji su Raveno progresuojančių matricu ir Verbalinio išprusimo testų rezultatais (vidurkiais). Pirmu atveju pri- 


\begin{tabular}{|c|c|c|c|c|}
\hline \multirow{13}{*}{$\begin{array}{l}1 \text { lentelè. Žemos ir aukš- } \\
\text { tos edukacijos grupių } \\
\text { lyginamoji aprašomoji } \\
\text { statistika }\end{array}$} & Skalė & Vidurkis ir moda & Žema edukacija & Aukšta edukacija \\
\hline & \multirow{2}{*}{ Dėmesingumo } & vidurkis & 0,76 & 0,88 \\
\hline & & moda & 0,90 & 0,93 \\
\hline & \multirow{2}{*}{ Loginio mąstymo } & vidurkis & 0,51 & 0,76 \\
\hline & & moda & 0,53 & 0,73 \\
\hline & \multirow{2}{*}{ Skaitmeninio mąstymo } & vidurkis & 0,42 & 0,61 \\
\hline & & moda & 0,30 & 0,60 \\
\hline & \multirow{2}{*}{ Erdvinio mąstymo } & vidurkis & 0,52 & 0,70 \\
\hline & & moda & 0,55 & 0,65 \\
\hline & \multirow{2}{*}{ Aritmetinio skaičiavimo } & vidurkis & 0,67 & 0,87 \\
\hline & & moda & 0,68 & 0,97 \\
\hline & \multirow{2}{*}{ Dėmesingumo } & vidurkis & 0,72 & 0,86 \\
\hline & & moda & 0,85 & 0,90 \\
\hline \multirow{12}{*}{$\begin{array}{l}2 \text { lentelè. Pasuktos matri- } \\
\text { cos komponentai }\end{array}$} & \multirow{2}{*}{ Pradiniai kintamieji — žinios } & \multicolumn{2}{|c|}{ Komponentai } & \\
\hline & & Tikslieji mokslai & Kalbos & Kiti mokslai \\
\hline & Matematikos & 0,92 & & \\
\hline & Tiksliujų mokslų & 0,89 & & \\
\hline & Fizikos & 0,86 & & \\
\hline & Chemijos & 0,64 & & \\
\hline & Informatikos & 0,56 & & \\
\hline & Užsienio kalbų & & 0,84 & \\
\hline & Humanitarinių mokslų & & 0,80 & \\
\hline & Lietuvių kalbos & & 0,75 & \\
\hline & Istorijos & & & 0,75 \\
\hline & Biologijos & & & 0,68 \\
\hline
\end{tabular}

klausomas kintamasis buvo Raveno testu gauti rezultatai (vidurkiai). Išanalizavus rezultatus pagal atskiras metodikos skales gauta, kad statistiškai reikšmingos sąsajos su Raveno testu yra pagal tris metodikos skales, kurios teoriškai labiausiai ir yra sietinos su minètu testu: loginio mąstymo skale $(\mathrm{p}=0,002)$, skaitmeninio mąstymo skale $(p=0,017)$ ir dvimačio erdvinio mąstymo (2D) skale $(\mathrm{p}=0,008)$. Raveno testo ivverčiu vidurkiai nèra statistiškai reikšmingai susiję su dėmesingumo ir aritmetinių skaičiavimų skalėmis $(p>0,05)$. Metodikos patikimumas tikrintas ir lyginant ją su Verbalinio išprusimo testo gautais rezultatais (vidurkiais). Išanalizavus rezultatus pagal atskiras metodikos skales gauta, kad statistiškai reikšmingos sąsajos su Verbalinio išprusimo testu yra pagal vieną metodikos skalę, kuri teoriškai ir sietina su minètu testu - loginio mąstymo skale $(\mathrm{p}=0,001)$. Verbalinio išprusimo testo įverčiu vidurkiai nèra statistiškai reikšmingai susiję su visomis kitomis metodikos skalèmis $(\mathrm{p}>0,05)$.

Sudarant Pažintinių gebejjimų testą jo patikimumui patikrinti, i̇vertinta skalių vidinè struktūra (Kronbacho $\alpha$ koeficientas). Nustatyta, kad visu skalių Kronbacho $\alpha$ koeficientai yra pakankamai aukšti (svyruoja nuo 0,63 iki 0,94) ir todèl priimtini testų teorijos požiūriu. Patikimumas tikrintas ivertinant Spirmeno ir Brauno koeficientą.
Dar vienas svarbus testo patikimumo įrodymas gautas taikant papildomą statistinę procedūrą daugiamačiu skaliu sudarymo (MDS) metodą. MDS privalumas tas, kad juo galima vizualizuoti duomenų, susijusių sudètingais ryšiais, aibes. I MDS modeli itrauktos visos šešios pažinimo funkcijų skalès. MDS rezultatai (Stress $=0.15$, $\mathrm{RSQ}=0.87$ ) pateikti 1 paveiksle. Taigi gautas teoriškai relevantiškas MDS modelis, suteikiantis papildomos informacijos apie testo psichometrini patikimumą.

Suskaičiavus pažintinių gebejjimų tyrimo metodikos skaliu aprašomają statistiką, konkrečiai užduočiu išspręstumą, paaiškèjo, kad tiek skalès tarpusavyje, tiek užduotys skalių viduje yra skirtingo sunkumo ir kartu labai nevienodai sprendžiamos. Aukščiausias išspręstumo rodiklis - 99\% (nustatytas dèmesingumo (1) ir aritmetinių skaičiavimu skalejje. Žemiausias išspręstumo procentas nustatytas dvimačio erdvinio mąstymo skaleje - $15 \%$. Minètoje skalëje užfiksuotas ir mažiausias maksimalus išspręstumo procentas - 94\%. Reziumuojant galima teigti, kad visų šešių metodikos skalių užduočių minimalus išspręstumas yra $15-30 \%$, maksimalus svyruoja nuo 94 iki 99\%.

Atlikta dispersinè analizè leido tarpusavyje palyginti tirtų lizdų skalių vidurkius. Pasirinkus reikšmingumo lygmeni $\alpha=0,01$, visi $p=0,000$. 

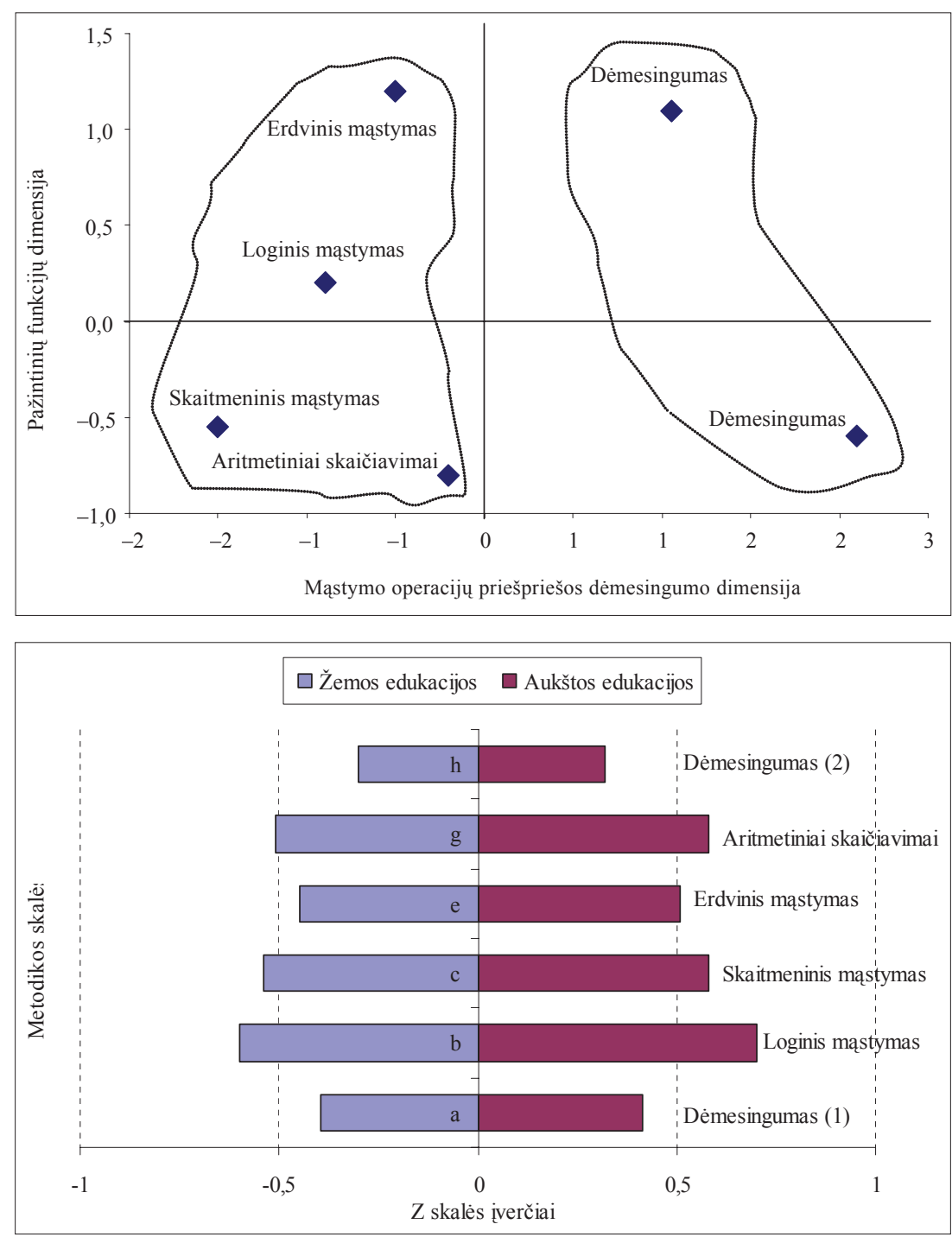

1 pav. MDS modelis (Stress $=\mathbf{0 . 1 5}$, RSQ $=0.87$
2 pav. Žemos ir aukštos edukacijos grupių rezultatų palyginimas $\mathrm{Z}$ skalèje
Vadinasi, nulinė hipotezè apie vidurkių lygybę atmetama (t. y. ne visi vidurkiai lygūs), kadangi visi $p<\alpha$. Kitaip tariant, skirtingų lizdų pažintiniu gebėjimų vidutiniai ịverčiai pagal visas skales yra skirtingi, t. y. metodika gerai diferencijuoja skirtingo lygmens tiriamuosius.

Gauti duomenys parodė ryškiai išsiskyrusius lizdų rezultatus, todèl buvo sudarytos dvi didelès tiriamuju grupès pagal edukaciniu pasiekimu lygi. Pirmai aukštos edukacijos grupei $(n=108)$ priskirti šie tiriamujų lizdai: universitetai, kuriuose studijuoja asmenys, pasirinkę tiksliuosius mokslus ir ekonomikos studijų krypti, statutinius darbuotojus rengianti akademija ir gimnazija. Antrai žemos edukacijos grupei $(n=118)$ priskirti šie tiriamuju lizdai: vidurinè mokykla, kolegija ir aukštesnioji mokykla. 1 lentelèje pateikiama lyginamoji aprašomoji statistika.

Perkèlus rezultatus į Z skalę, žemos ir aukštos edukacijos grupių skirtumai darosi dar akivaizdesni (žr. 2 pav.).
Palyginta, kaip skiriasi žemos ir aukštos edukacijos grupių Pažintinių gebejjimų, Raveno ir Verbaliniu gebėjimų testų išspręstumas. Grupėms lyginti panaudoti sukauptuju dažnių skirstiniai. Kaip žinoma, kuo ryškiau išsiskiria kreivès, tuo didesni yra skirtumai tarp grupių. Kaip ir buvo galima tikètis, visų trijų testų išspręstumas daug geresnis aukštos edukacijos grupèse. Išspręstumo skirtumus aukštos ir žemos edukacijos grupèse galima pamatyti 3,4 , ir 5 pav. Visais atvejais Studento kriterijus t testo modelyje parode, kad statistiniai sprendimai tenkina labai griežtą patikimumo sąlygą $(\mathrm{p} \leq 0,000)$.

Atlikta tiriamujų mokyklinių žinių subjektyvaus vertinimo faktorinè analizè. Anketoje tiriamieji privalejo įvertinti balais lietuviu kalbos, užsienio kalbos, istorijos, biologijos, matematikos, informatikos, fizikos ir chemijos žinias penkiu pakopu skaleje nuo „puikiai“ iki „blogai“.

Ar tarp stebimų kintamuju yra statistiškai reikšminga koreliacija, tikrinama Kaizerio, Meje- 
3 pav. Pažintinių gebėjimų testo užduočių išspręstinumo įvertis pagal tiriamųjų edukacijos grupę
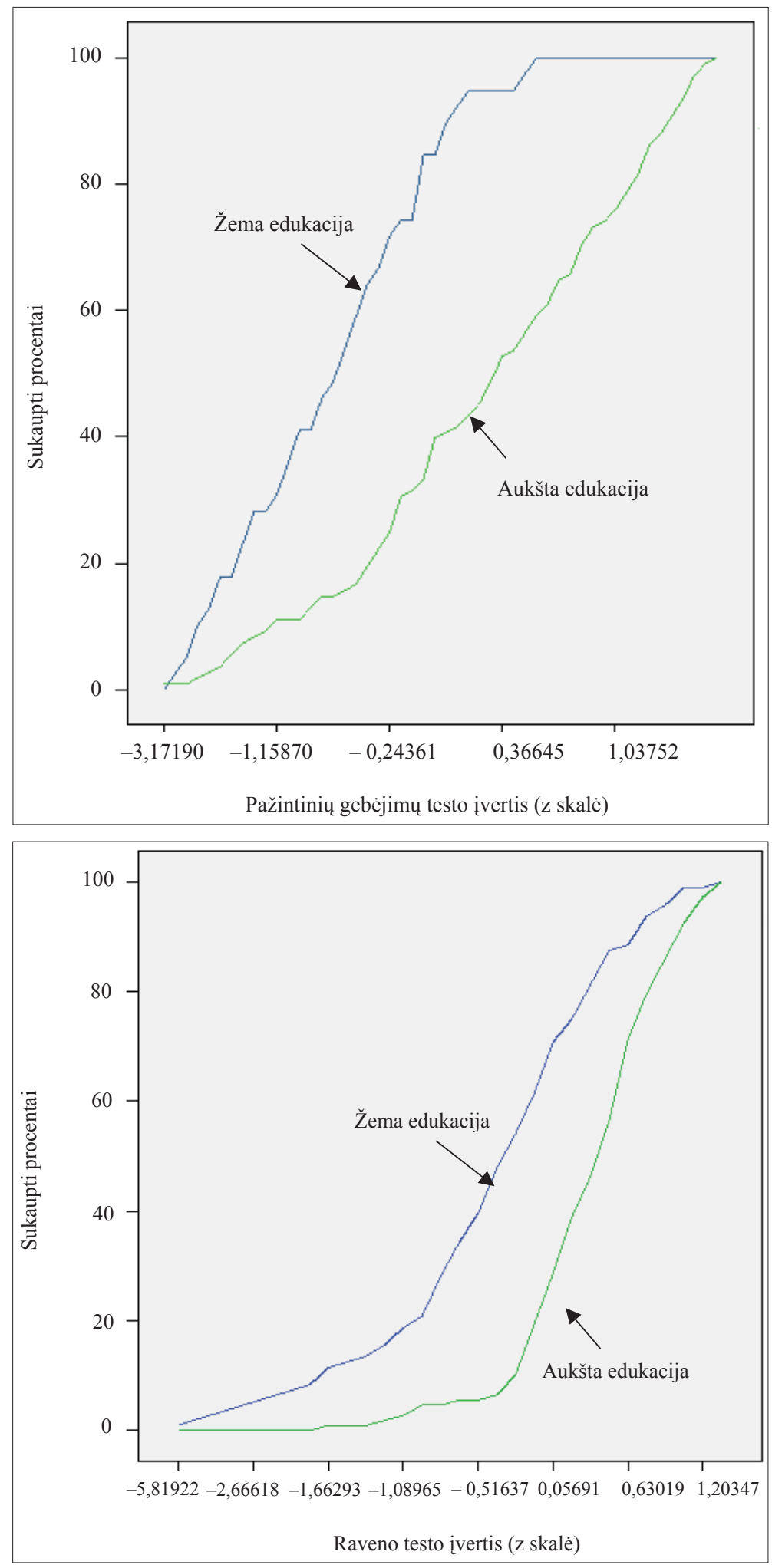

Trys komponentès paaiškina $67,8 \%$ bendrosios sklaidos (pirma iš ju $-32,0 \%$, antra $-20,7 \%$, trečia - 15,1\%).

Taip pat buvo apskaičiuotas faktoriu vidinis suderinamumas (vidinè struktūra), kuris yra nusakomas interkoreliacinių ryšiu išreikštumo laipsniu, apskaičiuojant Kronbacho $\alpha$ koeficientą. Gauta, kad tiksliuju mokslų Kronbacho $\alpha$ yra 0,85, kalbu $-0,74$. Trečio faktoriaus Kronbacho $\alpha$ koe- 


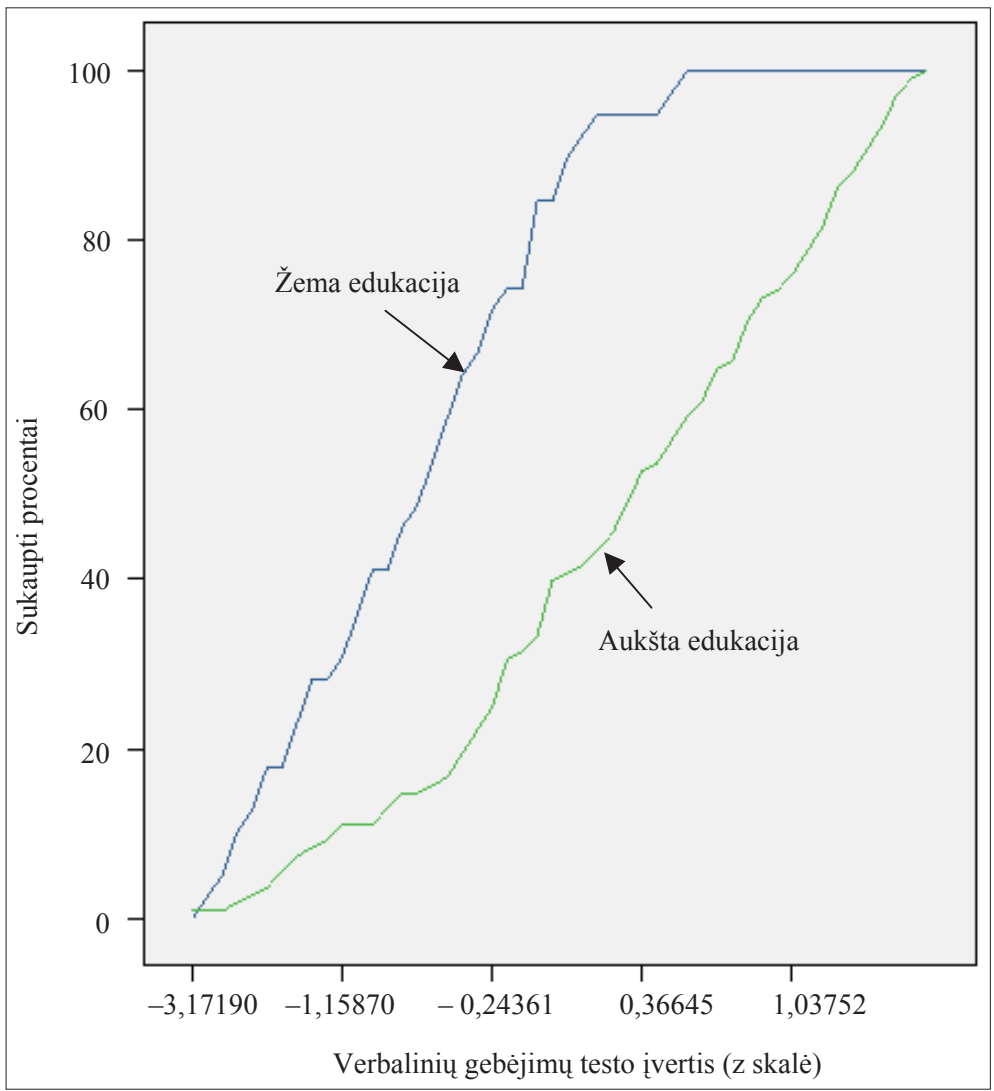

5 pav. Verbalinių užduočių išspręstumo įvertis pagal tiriamųjų edukacijos grupę

ficientas nebuvo skaičiuojamas, kadangi šiame faktoriuje yra tik du kintamieji.

Pritaikius regresinès analizès modelị, gautas bendrų pažintinių gebėjimų (visų testo skalių) rezultatų tiesioginis ryšys su subjektyviu tiksliujų mokslu žiniu ivertinimu. Gautas modelio aibinès koreliacijos koeficientas $r=0,51$, determinacijos koeficientas $\mathrm{r}^{2}=0,03$, regresijos modelio patikimumas $\mathrm{p}=0,001$.

Tiriant buvo surinkti duomenys ne tik apie subjektyvių tiriamujų žinių vertinimą, bet ir apie objektyvias žinias, t. y. paskutinių mokyklinių / universitetinių semestrų, egzaminų sesijų rezultatus (vidurkius). Apskaičiuoti Pirsono koreliacijos koeficientai tarp minètu rezultatų ir tyrimo duomenu pagal atskiras metodikos skales. Gauta, kad objektyvaus žiniu vertinimo koreliacija su dèmesingumu yra $0,29(\mathrm{p}=0,00)$, su loginiu mąstymu - 0,21 ( $\mathrm{p}=0,00)$, su skaitmeniniu mąstymu $-0,27(\mathrm{p}=0,00)$, su erdviniu mąstymu $0,16(\mathrm{p}=0,02)$, su aritmetiniais skaičiavimais $0,38(\mathrm{p}=0,00)$, su dèmesingumo antru tyrimu $0,33(\mathrm{p}=0,00)$.

\section{REZULTATUQ APTARIMAS}

Pažintinių gebejjimų matavimo problema psichologijos moksle iki šiol yra traktuojama labai kontroversiškai. Tokia situacija yra susiklosčiusi moksle ne tik dèl tebesitęsiančių teorinių diskusijų paties konstrukto definicijos klausimu, bet ir dèl tam tikrų metodologinių keblumų, kurie yra susiję su daugeliu tyrimus sunkinančių veiksnių. Vienas iš tokių veiksniu yra pažintiniu funkciju individualumas. Kadangi kiekvieno asmens pažintinès funkcijos yra labai savitos, tai sukurti instrumentą, leidžianti identifikuoti ir pamatuoti šias funkcijas, yra labai sudètinga. Šiuo tyrimu siekta sukonstruoti objektyvų, patikimą testą, kuris leistu ivertinti besimokančio jaunimo pažintinius gebejjimus. Todèl sukūrus testą ìvertintos jo psichometrinès ypatybės. Lyginant testą su Raveno ir Verbalinio išprusimo testu nustatyta, kad sukurtos Pažintiniu gebejjimų įvertinimo metodikos patikimumą galima traktuoti kaip pakankamą. Gauta, kad skalių vidinès struktūros koeficientai yra aukštesni nei 0,5 , todèl galima teigti, kad metodikos patikimumas taip pat yra pakankamas.

Kaip papildoma testo patikimumo tikrinimo procedūra naudotas daugiamačių skalių sudarymo (MDS) metodas. MDS taikoma tada, kai gautas dimensijas pavyksta teoriškai prasmingai interpretuoti ívardijant $\mathrm{x}$ ir y ašis. Šiuo atveju abscisių aši sąlygiškai galima vadinti „mąstymo ir dėmesingumo" operaciju priešpriešos dimensija, o ordinačių — „pažintinių funkciju““ dimensija. 
Horizontaliojoje (abscisių) ašyje (1 pav.) išryškejja poliškumas — dvi priešybès, kurias vienija su mąstymo operacijomis susijusi demesingumo priešpriešos dimensija. MDS modelyje matyti, kad skirtingose erdvès plotuose išsidèsto dèmesingumo skalès, iš kitos pusès - erdvinio, loginio, aritmetinio ir skaitmeninio mąstymo skalès. Mąstymo operaciju skalès kaireje pusèje nuo ašių centro nutolusios per $-0,5--1,5$ punkto. Dèmesingumo skalès dešinėje nutolusios nuo ašių centro net per $1-2$ punktus. Skirtumas tarp mąstymo operacijų ir demesingumo pozicijų siekia apie 1,5 punkto.

Dar derètu pastebèti, kad nedaug tenutolę vienas nuo kito diagramos erdveje yra skaitmeninis mąstymas, aritmetiniai skaičiavimai ir šiek tiek labiau nutolę, bet visgi artimi — erdvinis ir loginis mąstymas. Tai patvirtina, kad šios dimensijos iš esmès yra panašios.

Pažintinių gebejjimų metodikos aprašomosios statistikos duomenys atskleide, kad visos metodikos skalès ir užduotys šių skalių viduje yra labai skirtingai sprendžiamos. Apskaičiavus kiekvienos skalès užduočiu išspręstumo vidurkius paaiškejjo, kad geriausiai atliktos demesingumo užduotys: dèmesingumo (1) skalëje bendras išspręstumas sieke $81,7 \%$, dèmesingumo (2) - 78,7\%. Kiek prastesni rezultatai gauti aritmetiniu skaičiavimu $(77,0 \%)$, loginio mąstymo $(62,7 \%)$ ir erdvinio mąstymo skalèse $(60,3 \%)$. Žemiausias užduočių išspręstumo lygis nustatytas skaitmeninio mąstymo skalèje, kuris tesiekè tik 50,8\%.

Tyrimo rezultatai parodè, kad sukurta metodika gerai diferencijuoja skirtingo lygmens tiriamuosius, todèl sudarytos dvi grupès pagal edukaciniu pasiekimų lygi — žemos ir aukštos edukacijos. Nustatyta, kad aukštos ir žemos edukacijos grupių testo išspręstumas statistiškai reikšmingai skiriasi. Pažintiniai gebejjimai tarp šiu grupių ypač skiriasi loginio, skaitmeninio mąstymo ir aritmetiniu skaičiavimų skalèse. Mažiausias skirtumas yra dèmesingumo (2) skalèje.

Palyginus Raveno testo ir Verbalinių užduočių išspręstumą pagal tiriamujų edukacines grupes nustatyta, kad rezultatai daug geresni aukštos edukacijos grupèse. Visgi matyti, kad Pažintiniu gebejjimu testo išspręstumas aukštos ir žemos edukacijos grupèse skiriasi ryškiausiai. Galima daryti prielaidą - ši skirtumą lemia tai, kad Raveno progresuojančių matricų ir Verbaliniu užduočiu testai yra gana homogeniniai užduočiu prasme, tuo tarpu Pažintiniu gebejimų vertinimo metodikos skalès yra pakankamai skirtingos, apimančios keletą pažintinių funkcijų, todèl gerai diferencijuoja aukštos ir žemos edukacijos tiriamuosius.

Tyrimu mėginta aiškintis, kaip pažintiniai gebejjimai yra susiję su asmens mokyklinių žinių subjektyviu vertinimu. Tuo tikslu tiriamieji buvo paprašyti įvertinti ̨̇vairius mokyklinius dalykus. Tyrimo duomenys parodè, kad dalykai, kuriuos vertina tiriamieji, sudaro tris savarankiškus faktorius: tiksliuosius mokslus, kalbas ir kitus mokslus, susijusius su informacijos isimini$\mathrm{mu}$ ir pasakojimu (istorija ir biologija). Bandant nustatyti ryši tarp pažintinių gebejimų ir subjektyvaus žinių ịvertinimo, gautas vienas statistiškai patikimas ryšys tarp pažintiniu gebejjimų visų testo skalių (bendro vertinimo) ir subjektyvaus tiksliujų žinių i̇vertinimo.

Kaip minèta, mokslininkus seniai domino ir iki šiol tebedomina klausimas, koks ryšys sieja pažintinius gebejjimus ir objektyvius mokymosi pasiekimus (Deary et al., 2007). Šiuo tyrimu taip pat mėginta ieškoti atsakymo į minètą klausimą. Tuo tikslu buvo surinkti duomenys apie tiriamujų paskutinių mokyklinių / universitetiniu semestrų, egzaminu sesijų rezultatus. Gauta, kad objektyvus žinių ịvertinimas teigiamai koreliuoja su visomis pažintiniu gebejjimu skalemis. Tačiau stipriausias statistiškai reikšmingas ryšys yra tarp Pažintiniu gebejjimų testo aritmetinių skaičiavimu iverčių ir mokyklinių / universitetinių semestrų, egzaminų sesijų rezultatų vidurkių. Nors gauti ryšiai nèra tokie stiprūs, kaip nurodo kai kurie autoriai (Gustafson, Undheim, 1996; Deary, et al., 2007), pastebima, kad vertinimo objektyvumas siejasi su žemesniu išsimokslinimo lygiu. Kitaip tariant, jauniausių tiriamujų žinių i̇vertinimas yra objektyvesnis nei vyresniujų. Vyresniujuc klasių mokinių ir studentų pažymiai dažnokai būna ne visiškai objektyvūs - viena vertus, dèl mokytojų ir dèstytojų neobjektyvaus vertinimo, antra vertus, del to, kad priklauso nuo mokymosi motyvacijos bei kitų mokinio ar studento asmenybès ypatumu.

Straipsnyje pristatomas eksploracinis tyrimas atskleidè neabejotiną ryši tarp tirtų mokinių ir studentų pažintinių gebejjimų bei edukacinių pasiekimų. Ateityje ši tyrimą numatoma plètoti papildant tiriamujuc imtị ir ieškant pažintiniu gebejjimu sąsajų su kai kuriomis tiriamujų psichologinemis bei demografinèmis ypatybèmis. 


\section{IŠVADOS}

1. Sukurta nauja originali Pažintinių gebejjimu ivertinimo metodika, tinkanti vertinti šias pažintines funkcijas: dèmesio ypatumus (tikslumą ir pastabuma), loginio mąstymo savybes, skaitmeninio mastymo ypatumus, erdvinio mąstymo gebejimus, aritmetinių skaičiavimų spartą ir kokybę. Metodikos patikimumas yra pakankamas (konstrukcinis patikimumas tikrintas atliekant konvergentinę validizaciją su Raveno progresyvinių matricu testu ir su G. Merkio Verbalinio išprusimo testu). Metodikos patikimumas yra pakankamas (tikrinta pagal Spirmeno-Brauno koeficientą). Vidinè metodikos struktūra yra gera.
2. Metodika gerai diferencijuoja skirtingo lygmens tiriamuosius. Nustatyti pakankamai ryškūs pažintinių funkcijų skirtumai aukštos ir žemos edukacijos tiriamujuc grupèse: geresni pažintinių gebejjimų skalių rezultatai gauti aukšto edukacijos lygio tiriamujų grupèse.

3. Gautas bendrų pažintinių gebejjimų (visų testo skalių) rezultatų tiesioginis ryšys su subjektyviu tiksliujų mokslų žinių įvertinimu.

4. Objektyvūs besimokančiujų žinių vertinimai (t. y. egzaminų vidurkiai) yra statistiškai patikimai susiję su visais pažintinių gebèjimų metodikos skalių (dèmesingumo, loginio, skaitmeninio, erdvinio, aritmetinių skaičiavimų) vertinimų vidurkiais.

\section{LITERATŪRA}

Ackerman, P. L. (1996). A theory of adult intellectual development: Process, personality, interests, and knowledge. Intelligence, 22, 229-259.

Ackerman, P. L., Rolfhus, E. L. (1999). The Locus of adult intelligence. Knowledge, abilities, and nonability traits. Journal of Educational Psychology, 14 (2), 314-330.

Ashcraft, M. (1989). Human Memory and Cognition. Glen-view, IL: Scott, Foresman.

Boyatzis, R. E. (2008 a). A 20-year view of trying to develop emotional, social and cognitive intelligence competencies in graduate management education. Journal of Management Development, 27 (1), 92-108.

Boyatzis, R. E. (2008 b). Competencies in the 21 st century. Journal of Management Development, 27 (1), 5-12.

Cianciolo, A. T., Sternberg, R. J. (2004). Intelligence: A Brief History. Oxford, UK: Blackwell Publishing.

Deary, I. J., Strand, S., Smith, P., Fernandes, C. (2007). Intelligence and educational achievement. Intelligence, 35 (1), 13-21.

Eysenck, H. J. (1987). Speed of information processing, reaction time, and the theory of intelligence. P. A. Vernon (Ed.), Speed of Information-processing and Intelligence (pp. 21-67). Ablex, Norwood, NJ.

Fink, A., Neubauer, A. C. (2005). Individual differences in time estimation related to cognitive ability, speed of information processing and working memory. Intelligence, 33 (1), 5-26.

Gottfredson, L. S. (2004). Intelligence: Is it the epidemiologists' elusive "fundamental cause" of social class inequalities in health? Journal of Personality and Social Psychology, 86, 174-199.

Gustafson, J. E., Undheim, J. O. (1996). Individual differences in cognitive functions. D. C. Berliner, R. C. Calfee (Eds.), Handbook of Educational Psychology (pp. 186242). New York: Simon \& Schuster Macmillan.
Herrnstein, R. J., Murray, C. (1994). The Bell Curve. New York: Free Press.

Kuncel, N. R., Hezlett, S. A., Ones, D. S. (2004). Academic performance, career potential, creativity, and job performance: Can one construct predict them all? Journal of Personality and Social Psychology, 86, 148-161.

Kyllonen, P. C. (1993). Aptitude testing inspired by information processing: A test of the four-sources model. The Journal of General Psychology, 120, 375-405.

Leonard, D. C. (2008). The impact of learning goals on emotional, social, and cognitive intelligence competency development. Journal of Management Development, 27 (1), 109-128.

Lohman, D. F., Hagen, E. P. (2001). Cognitive Abilities Test (Form 6). Itasca, IL: Riverside.

Lupart, J. L. (1992). The hidden gifted: Current state of knowledge and future research directions. In F. J. Monks, W. A. M. Peters (Eds.), Talent for the Future (pp. 177190). Assen: Van Gorcum

Neubauer, A. C. (1997). The mental speed approach to the assessment of intelligence. In J. Kingma, W. Tomic (Eds.), Advances in Cognition and Education Practice: Reflections on the Concept of Intelligence (pp. 149-174). Greenwich, Connecticut: JAI Press.

Robinson, D. L. (1999). The 'IQ' factor: Implications for intelligence theory and measurement. Personality and Individual Differences, 27, 715-735.

Spinath, B., Spinath, F., Harlaar, N., Plomin, R. (2006). Predicting achievement from general cognitive ability, self-perceived ability, and intrinsic value. Intelligence, 34 (4), 363-374.

Watkins, M. W., Pui-Wa, Lei, Canivez, G. L. (2007). Psychometric intelligence and achievement: A cross-lagged panel analysis. Intelligence, 35 (2), 59-68. 


\title{
COHESION BETWEEN COGNITIVE FUNCTIONS AND EDUCATIONAL ACHIEVEMENTS IN STUDENTS' POPULATION
}

\author{
Dalia Antiniené, Rosita Lekavičienė \\ Kaunas University of Technology, Kaunas, Lithuania
}

\begin{abstract}
Cognitive ability is an ability to use cognitive functions - attention, memory, logical, spatial thinking, etc. Usually they are associated with many external variables. However, a peculiar cohesion exists between them and educational achievements. Foreign scientists emphasize high correlation between these phenomena. The search for similar surveys in Lithuania failed although it wouldn't be difficult to get a fairly correct prognosis of study achievements knowing specific cognitive abilities of people in a particular age group.

The purpose of the research was to reveal how cognitive functions of students were related to educational factors, such as educational level, study achievements, subjective assessment of achievements. The objectives of research were as follows: to present the validity and reliability characteristics of cognitive ability analysis methodology; to reveal and to compare the characteristics of cognitive abilities typical to the students with different educational levels; to establish how different educational level, subjective and objective assessment of knowledge were related to the cognitive abilities of students.

The cognitive ability analysis methodology consists of these structural parts: attentiveness, logical thinking, numerical thinking, two-dimensional and three-dimensional spatial thinking and arithmetical calculation tasks. The validity and reliability of methodology is sufficient. The internal consistency of methodology is good. Research subjects were given Raven Progressive Matrices and Verbal Proficiency Tests by G. Merkys together with cognitive ability analysis methodology. 226 respondents participated in this research. The research was conducted at different level educational institutions: universities, colleges, vocational schools, secondary schools and gymnasia.

It was established that this methodology can well differentiate subjects of different educational levels. Sufficiently distinct cognitive ability differences have been determined in low and high education subject groups: higher cognitive ability scale results have been obtained in high education level subject groups. Subjective assessment of students' knowledge showed the cohesion between all cognitive ability scales and subjective assessment of knowledge of exact sciences. Objective assessments of student knowledge (i. e., exam averages) are statistically reliably related to all cognitive ability methodology scale assessment averages.
\end{abstract}

Keywords: cognitive ability, educational achievements, high and low educational level.

Gauta 2009 m. kovo 4 d.

Received on March 4, 2009

Priimta 2009 m. gegužès 6 d.

Accepted on May 6, 2009

Dalia Antinienè

Kauno technologijos universitetas

(Kaunas University of Technology)

K. Donelaičio g. 20, LT-44239 Kaunas

Lietuva (Lithuania)

Tel +370 37771174

E-mail dalia.antiniene@ktu.lt 